\title{
PENGARUH UKURAN PERUSAHAAN, PROFITABILITAS DAN LEVERAGE TERHADAP MANAJEMEN LABA
}

\author{
Siti Wulan Astriah ${ }^{1}$, Rizky Trinanda Akhbar ${ }^{2}$, Erma Apriyanti ${ }^{3 *}$, Dewi Sarifah Tullah ${ }^{4}$ \\ 1,2,3,4Sekolah Tinggi Ilmu Ekonomi Pandu Madania, astriahwulan@gmail.com; \\ akhbar.rizky@gmail.com; apriyantierma82@gmail.com*(Corresponding Author); \\ dewisarifahtullah@gmail.com
}

\begin{abstract}
ABSTRAK
Penelitian ini bertujuan untuk mengetahui pengaruh ukuran perusahaan, profitabilitas dan leverage terhadap manajemen laba perusahaan manufaktur yang terdaftar di BEI. Populasi dalam penelitian ini adalah perusahaan manufaktur yang terdaftar di BEI periode 2017-2019. Teknik pengambilan sampel dilakukan dengan metode purposive sampling. Data yang digunakan merupakan data sekunder yang diperoleh melalui teknik dokumentasi yang berupa laporan keuangan perusahaan yang diterbitkan oleh website Indonesia Stock Exchange (IDX). Metode analisis data yang digunakan dalam penelitian ini analisis deskriptif, uji asumsi klasik dan analisis regresi linear berganda dengan menggunakan aplikasi statistik EViews versi 11 sebagai alat uji. Hasil penelitian menunjukkan bahwa secara parsial ukuran perusahaan tidak berpengaruh terhadap manajemen laba, profitabilitas berpengaruh positif terhadap manajemen laba dan leverage tidak berpengaruh terhadap manajemen laba. Sedangkan, secara simultan hasil penelitian menunjukkan bahwa ukuran perusahaan, profitabilitas dan leverage mempengaruhi manajemen laba. Hendaknya para investor dan kreditor sebaiknya lebih berhati-hati dalam menginvestasikan dan meminjamkan dana yang dimilikinya, karena perusahaan dengan profitabilitas yang tinggi terbukti melakukan manajemen laba yang tinggi.
\end{abstract}

Kata kunci: Ukuran Perusahaan, Profitabilitas, Leverage, Manajemen Laba.

\begin{abstract}
The purpose of this research is to find out the effect of firm size, profitability and leverage toward earnings management of registered manufacturing company in BEI. The population in this research is all of registered manufacturing company in BEI for the 2017-2019 period. The sampling the sampling techniques is purposive sampling method. The data used the secondary data obtained through documentation techniques in the form of company financial statement published by the Indonesia Stock Exchange website. Data analysis method used in this research is descriptive statistical analysis, classis assumption test and multiple linear regression analysis using the EViews statistical application version 11 as a test tool. The result of the research showed that partially firm size has no significant effect toward earnings management, profitability has a positive effect toward earnings management and leverage has no significant effect toward earnings management. Furthermore, simultaneously the result of the research showed that firm size, profitability and leverage affect earnings management. Investors and creditors should be more careful in investing and lending their funds, because companies with high profitability are proven to have high earnings management.
\end{abstract}

Keywords: firm size, profitability, leverage, earnings management 
Naskah diterima : 29-11-2021, Naskah dipublikasikan : 30-11-2021

\section{PENDAHULUAN}

Perkembangan dunia bisnis semakin cepat, laporan keuangan menjadi sarana penting untuk membuat keputusan bagi setiap perusahaan. Menurut Pernyataan Standar Akuntansi Keuangan (PSAK) No. 1 (IAI, 2014), laporan keuangan adalah presentasi terstruktur dari posisi keuangan dan manfaat finansial suatu entitas. Tujuan laporan keuangan adalah untuk menyediakan informasi tentang posisi keuangan, kinerja keuangan dan arus kas entitas yang menguntungkan bagi semua kalangan pengguna laporan dalam membantu membuat suatu keputusan ekonomi. Laporan keuangan dapat dikatakan sebagai bentuk pertanggungjawaban yang dibuat oleh pihak manajemen terhadap penggunaan atas seluruh sumber daya yang dimiliki perusahaan. Standar ini juga menyebutkan salah satu komponen laporan keuangan adalah laporan laba rugi, yang merupakan suatu laporan keuangan yang di dalamnya menjelaskan tentang kinerja keuangan suatu entitas bisnis dalam satu periode akuntansi. Laba sering digunakan sebagai ukuran kinerja atau sebagai dasar untuk pengukuran lain, seperti tingkat pengembalian investasi atau laba per saham. Oleh karena itu, laporan laba rugi merupakan salah satu bagian yang menjadi sasaran kegiatan manipulasi yang dilakukan oleh manajemen. Untuk mencapai suatu target laba, dilakukan dengan cara memilih kebijakan akuntansi yang ditujukan agar perusahaan dapat menaikkan atau menurunkan laba yang diperoleh sesuai dengan kebutuhan dan keinginan manajemen agar laporan keuangan perusahaan terlihat baik dimata para pengguna. Perilaku tersebut dikenal dengan istilah manajemen laba (earnings management).

Menurut Sulistyanto (2008), terdapat perbedaan mendasar antara praktisi dan akademisi dalam memandang dan memahami manajemen laba. Secara umum, para praktisi, yaitu investor, pemerintah, asosiasi profesi dan ekonomi lainnya, menganggap manajemen laba sebagai kecurangan manajerial. Hal ini dikarenakan aktivitas manajerial ini dilakukan untuk menyesatkan dan merugikan pihak lain yang menggunakan laporan keuangan sebagai sumber informasi untuk mengetahui segala sesuatu tentang perusahaan. Sedangkan bagi akademisi, termasuk para peneliti, menilai manajemen laba bukan sebagai kecurangan, hal ini disebabkan aktivitas rekayasa manajerial ini pada dasarnya merupakan dampak dari luasnya spektrum Prinsip Akuntansi yang Berlaku Umum (PABU). Prinsip akuntansi menyediakan beragam metode dan prosedur yang dapat dipilih dan dipergunakan sesuai dengan tujuan yang ingin dicapai perusahaan. Pengukuran manajemen laba dalam penelitian ini menggunakan proksi Discretionary Accrual (DA), yang merupakan komponen akrual yang berada dalam kebijakan manajemen, artinya manajer dan manajemen memberikan kontribusinya dalam proses pelaporan keuangan. Hal ini membuktikan bahwa manajer dan manajemen dapat memanipulasi pendapatan akrual dan biasanya digunakan untuk mencapai pendapatan yang diinginkan.

Hingga saat ini manajemen laba masih menjadi fenomena yang umum terjadi dikalangan perusahaan. Beberapa kasus manajemen laba yang terjadi di Indonesia khususnya pada emiten manufaktur yaitu antara lain PT. Ades Alfindo Tbk dan PT. Kimia Farma Tbk. Dari sektor jasa infrastruktur yaitu PT. Inovisi Infracom Tbk. Kemudian salah satu fenomena manajemen laba yang terbaru yaitu kasus yang terjadi pada PT Garuda Indonesia (Persero) Tbk (IDX:GIAA). Terdapat beberapa faktor yang dapat mempengaruhi manajer untuk melakukan manajemen laba, diantaranya adalah ukuran perusahaan, profitabilitas dan leverage. Ukuran perusahaan pada dasarnya adalah pengelompokkan perusahaan kedalam beberapa kelompok, di antaranya perusahaan besar, sedang dan kecil. Menurut Sosiawan (2012), ukuran perusahaan merupakan salah satu tolok ukur yang menunjukkan besar kecilnya suatu perusahaan. Pengukuran ukuran perusahaan dalam penelitian ini menggunakan proksi log natural (Ln) dari total aktiva perusahaan. Dengan menggunakan log natural, jumlah asset dengan nilai ratusan miliar hingga triliun akan disederhanakan, tanpa mengubah proporsi dari jumlah aset yang 
sesungguhnya. Berdasarkan uraian di atas, ukuran perusahaan dapat memberikan pengaruh pada manajemen laba. Perusahaan yang lebih besar biasanya akan memiliki lebih banyak perhatian dari pihak eksternal, seperti investor, analis, maupun pemerintah. Oleh sebab itu perusahaan akan menghindari kenaikan laba yang terlalu drastis, dikarenakan hal itu akan menyebabkan pertambahan kewajiban seperti pajak. Semakin tinggi ukuran perusahaan, maka perusahaan cenderung akan melakukan manajemen laba dengan cara perataan atau meminimumkan laba. Sejalan dengan penelitian yang telah dilakukan oleh Wibisana \& Ratnaningsih (2014) dan Lubis \& Suryani (2018) yang menyatakan bahwa ukuran perusahaan berpengaruh positif terhadap praktik laba. Sedangkan Sosiawan (2012) dan Agustia \& Suryani (2018) menyatakan bahwa ukuran perusahaan tidak berpengaruh terhadap manajemen laba.

Faktor selanjutnya yaitu profitabilitas, yang merupakan salah satu indikator yang penting untuk menilai suatu perusahaan. Menurut Sudana (2019) mengemukakan bahwa profitabilitas adalah rasio untuk mengukur kemampuan perusahaan untuk menghasilkan laba dengan menggunakan sumber-sumber yang dimiliki perusahaan seperti aktiva, modal atau penjualan perusahaan. Pengukuran profitabilitas dalam penelitian ini menggunakan Return On Assets (ROA), dikarenakan rasio ini mengukur kemampuan perusahaan secara keseluruhan dalam menghasilkan laba dengan jumlah keseluruhan aktiva yang dimiliki perusahaan. Seperti ukuran perusahaan, profitabilitas yang dihasilkan perusahaan juga akan mempengaruhi manajemen laba, dikarenakan semakin tinggi profit yang dihasilkan maka manajemen akan melakukan tindakan untuk membuat laba terlihat stabil untuk menghindari pajak. Sejalan dengan penelitian yang telah dilakukan oleh Purnama (2017) dan Puspitosari (2015) yang menyatakan bahwa profitabilitas berpengaruh positif terhadap manajemen laba. Sedangkan Agustia \& Suryani (2018) dan Sari (2015) menyatakan bahwa profitabilitas tidak berpengaruh terhadap manajemen laba.

Faktor lain yaitu leverage, adalah rasio yang digunakan untuk mengukur sejauh mana aktiva perusahaan dibiayai dengan utang. Maksudnya, besar beban utang yang ditanggung perusahaan akan dibandingkan dengan aktivanya (Kasmir, 2016). Pengukuran leverage dalam penelitian ini menggunakan Debt to Equity Ratio (DER), dikarenakan rasio ini merupakan rasio yang digunakan untuk menilai hutang dengan ekuitas. Seperti halnya ukuran perusahaan dan profitabilitas, leverage yang dihasilkan perusahaan juga akan mempengaruhi manajemen laba, semakin tinggi utang yang dimiliki maka manajemen akan melakukan tindakan untuk menggunakan metode-metode akuntansi yang dapat meningkatkan laba. Sejalan dengan penelitian yang telah dilakukan oleh Sosiawan (2012) dan Sari (2015) yang menyatakan bahwa leverage berpengaruh positif terhadap manajemen laba. Sedangkan Purnama (2017) dan Puspitosari (2015) menyatakan bahwa leverage tidak berpengaruh terhadap manajemen laba.

Penelitian terdahulu yang menguji mengenai manajemen laba telah banyak dilakukan. Namun hasil yang didapat dari beberapa penelitian tidak konsisten. Terdapat research gap yang signifikan antar hasil penelitian, hal ini mendorong penulis untuk melakukan penelitian ini. Judul yang digunakan pada penelitian ini adalah "Pengaruh Ukuran Perusahaan, Profitabilitas, dan Leverage terhadap Manajemen Laba (Studi Kasus pada Perusahaan Manufaktur yang Terdaftar di Bursa Efek Indonesia Tahun 2017-2019)". Adapun tujuan penelitian yang ingin dicapai adalah: (1) untuk mengetahui apakah ukuran perusahaan berpengaruh positif terhadap manajemen laba. (2) untuk mengetahui apakah profitabilitas berpengaruh positif terhadap manajemen laba. (3) untuk mengetahui apakah leverage berpengaruh positif terhadap manajemen laba. 


\section{KAJIAN LITERATUR}

\section{Ukuran Perusahaan}

Menurut Azlina (2010), ukuran perusahaan adalah suatu skala dimana dapat diklasifikasikan besar dan kecilnya perusahaan dengan berbagai cara, antara lain: total aktiva, log size, nilai pasar saham, dan lain-lain. Perusahaan yang lebih besar umumnya akan mendapatkan lebih banyak perhatian dari pihak eksternal, seperti investor, analis, maupun pemerintah. Oleh sebab itu perusahaan akan menghindari kenaikan laba yang terlalu drastis, hal ini akan menyebabkan pertambahan kewajiban seperti pajak. Perusahaan besar akan cenderung berusaha untuk melaporkan perolehan laba yang stabil setiap tahunnya.

Berdasarkan dari definisi tersebut maka ukuran perusahaan dinilai dapat berpengaruh positif terhadap manajemen laba, karena semakin tinggi ukuran perusahaan maka akan semakin tinggi kemungkinan perusahaan melakukan manajemen laba. Hal ini sejalan dengan penelitian Lubis \& Suryani (2018) yang memperoleh hasil bahwa ukuran perusahaan memiliki pengaruh positif terhadap manajemen laba.

\section{Profitabilitas}

Sudana (2019) mengemukakan bahwa profitabilitas adalah rasio untuk mengukur kemampuan perusahaan untuk menghasilkan laba dengan menggunakan sumber-sumber yang dimiliki perusahaan seperti aktiva, modal atau penjualan perusahaan. Sedangkan menurut Kasmir (2016), profitabilitas adalah rasio untuk menilai kemampuan perusahaan dalam mencari keuntungan. Rasio ini juga memberikan ukuran tingkat efektivitas manajemen suatu perusahaan. Hal ini ditunjukkan oleh laba yang dihasilkan dari penjualan dan pendapatan investasi. Semakin baik atau tinggi nilai dari rasio profitabilitas, maka akan semakin baik pula kemampuan perusahaan dalam mendapatkan keuntungan.

Berdasarkan dari definisi tersebut maka profitabilitas dinilai dapat berpengaruh positif terhadap manajemen laba. Keterkaitan profitabilitas dengan manajemen laba adalah ketika profitabilitas yang diperoleh perusahaan tinggi pada periode waktu tertentu akan memicu perusahaan untuk melakukan manajemen laba dengan cara mengurangi pendapatan yang diperoleh sehingga akan mengurangi tingkat pajak. Hal ini sejalan dengan penelitian Purnama (2017) yang memperoleh hasil bahwa profitabilitas memiliki pengaruh positif terhadap manajemen laba.

\section{Leverage}

Menurut Herispon (2016), leverage merupakan suatu jaminan, yang mengukur kemampuan perusahaan untuk membayar hutangnya bila satu saat perusahaan dibubarkan. Atau seberapa jauh perusahaan difinansir oleh pihak luar atau kreditor. Sedangkan menurut Kasmir (2016), pengertian leverage adalah rasio yang digunakan untuk mengukur sejauh mana aktiva perusahaan dibiayai dengan utang. Artinya, berapa besar beban utang yang ditanggung perusahaan dibandingkan dengan aktivanya.

Berdasarkan dari definisi tersebut maka leverage dinilai dapat berpengaruh positif terhadap manajemen laba. Perusahaan yang memiliki rasio leverage yang tinggi berarti memiliki proporsi utang yang lebih besar dibandingkan dengan proporsi aktiva yang dimiliki sehingga akan cenderung melakukan manipulasi dalam bentuk manajemen laba untuk menghindari perjanjian utang. Semakin tinggi tingkat rasio leverage suatu perusahaan akan berdampak pada semakin tinggi pula resiko yang akan dihadapi perusahaan, hal itu akan memicu perusahaan untuk meningkatkan laba. Hal ini sejalan dengan penelitian (Sari, 2015) yang memperoleh hasil bahwa leverage memiliki pengaruh positif terhadap manajemen laba. 


\section{METODE PENELITIAN}

Objek yang digunakan dalam penelitian ini adalah ukuran perusahaan, profitabilitas, leverage dan manajemen laba pada. Unit penelitian dilakukan pada perusahaan manufaktur yang terdaftar di Bursa Efek Indonesia (BEI) pada tahun 2017 sampai dengan tahun 2019. Populasi dalam penelitian ini adalah semua perusahaan manufaktur yang terdaftar di Bursa Efek Indonesia tahun 2017-2019 sebanyak 160 perusahaan. Penentuan sampel menggunakan metode purposive sampling yaitu teknik pengambilan sampel sumber data dengan pertimbangan tertentu (Widodo \& Andawaningtyas, 2017). Berdasarkan kriteria dipilih 81 perusahaan yang dijadikan sampel. Jenis data yang digunakan dalam penelitian ini adalah data sekunder, yang merupakan data catatan yang telah ada yang merupakan hasil rekap laporan keuangan. Data dalam penelitian ini diambil dari laporan keuangan perusahaan manufaktur yang terdaftar di BEI tahun 2017-2019 yang dikeluarkan oleh Indonesia Stock Exchange (IDX) melalui situs resmi BEI yaitu www.idx.co.id. Adapun teknik pengumpulan data dalam penelitian ini adalah dokumentasi. Variabel dependen dalam penelitian ini adalah manajemen laba. Sedangkan variabel independen dalam penelitian ini terdiri dari ukuran perusahaan, profitabilitas dan leverage.

1) Manajemen laba diukur dengan Discretionary Accrual (akrual diskresioner), yang merupakan komponen akrual yang berada dalam kebijakan manajemen. Berikut alur rumus dan alur perhitungan manajemen laba dengan Model Modifikasi Jones (Dechow et al., 1995).

a) Menghitung Total Accrual (TAC)

TAC $=$ NIit - CFOit

Keterangan:

TAit = Total Accrual perusahaan i dalam periode tahun $\mathrm{t}$;

NIit = Laba Bersih perusahaan i dalam periode tahun $\mathrm{t}$;

CFOit = Arus Kas dari aktivitas operasi perusahaan i dalam periode tahun $\mathrm{t}$.

b) Menghitung Total Accrual (TAC) dengan Ordinary Least Square (OLS) untuk mendapatakan koefisien regresi

TAit/Ait-1 $=\beta 1(1 /$ Ait-1) $+\beta 2(\Delta$ REVit/Ait-1) $+\beta 3($ PPEit/Ait-1) $+\varepsilon$

Keterangan:

Tait $\quad=$ Total Accrual perusahaan i dalam periode tahun $\mathrm{t}$;

Ait-1 $\quad=$ Total Assets perusahaan i dalam periode tahun $\mathrm{t}-1$;

$\triangle$ REVit $\quad=$ Pendapatan perusahaan i pada tahun $\mathrm{t}$ dikurangi dengan pendapatan perusahaan i pada tahun $\mathrm{t}-1$;

PPEit $\quad=$ Total Aset Berwujud perusahaan i dalam periode tahun $\mathrm{t}$;

$\beta 1, \beta 2, \beta 3 \quad=$ Parameter yang diperoleh dari persamaan regresi;

$\varepsilon \quad=$ Error.

c) Menghitung Nondiscretionary Accrual (NDA)

NDAit $\quad=\beta 1(1 /$ Ait- 1$)+\beta 2((\Delta$ REVit/Ait- 1$)+(\Delta$ RECit/Ait- 1$))+\beta 3$ (PPEit/Ait-1)

Keterangan:

NDAit $\quad=$ Nondiscretionary Accruals perusahaan i dalam periode tahun $\mathrm{t}$;

Tait $\quad=$ Total Accrual perusahaan i dalam periode tahun $\mathrm{t}$;

Ait-1 = Total Assets perusahaan i dalam periode tahun $\mathrm{t}-1$;

$\triangle$ REVit $\quad=$ Pendapatan perusahaan $\mathrm{i}$ pada tahun $\mathrm{t}$ dikurangi dengan pendapatan perusahaan i pada tahun $\mathrm{t}-1$;

$\triangle$ RECit $=$ Piutang Usaha perusahaan i pada tahun $\mathrm{t}$ dikurangi pendapatan perusahaan i pada tahun t-1; 
PPEit $\quad=$ Total Aset Berwujud perusahaan $\mathrm{i}$ dalam periode tahun $\mathrm{t}$;

$\beta 1, \beta 2, \beta 3 \quad=$ Parameter yang diperoleh dari persamaan regresi.

d) Menghitung Discretionary Accrual (DA)

DAit $=($ TAit $/$ Ait-1 $)-$ NDAit

Keterangan :

DAit = Discretionary Accruals perusahaan i dalam periode tahun t;

TAit $=$ Total Accrual perusahaan i dalam periode tahun $\mathrm{t}$;

Ait-1 = Total Assets perusahaan i dalam periode tahun $\mathrm{t}-1$;

NDAit $=$ Nondiscretionary Accruals perusahaan i dalam periode tahun $\mathrm{t}$;

2) Menurut Sosiawan (2015) ukuran perusahaan merupakan salah satu tolok ukur yang menunjukkan besar kecilnya suatu perusahaan. Ukuran perusahaan dapat diproyeksikan dengan rumus Size $=$ Log natural Total Aset.

3) Menurut Sudana (2009), profitabilitas adalah rasio untuk mengukur kemampuan perusahaan untuk menghasilkan laba dengan menggunakan sumber-sumber yang dimiliki perusahaan seperti aktiva, modal atau penjualan perusahaan. Dalam penelitian ini alat ukur yang digunakan untuk mengukur profitabilitas adalah ROA (Return on Assets) dengan rumus: Laba Bersih / Total Asset.

4) Menurut Harahap (2013), leverage adalah suatu rasio yang digunakan untuk mengukur sejauh mana aktiva perusahaan dibiayai dengan utang. Artinya, berapa besar beban utang yang ditanggung perusahaan dibandingkan dengan aktivanya. Dalam penelitian ini alat ukur yang digunakan untuk mengukur leverage adalah Debt to Equity Ratio (DER) dengan rumus: Total Hutang / Total Ekuitas

Teknik analisis data yang digunakan penelitian ini adalah statistik deskriptif, uji asumsi klasik dan regresi data panel berganda. Statistik deskriptif yang digunakan untuk mendeskripsikan data yang ada dalam penelitian ini. Alat analisis yang digunakan dalam penelitian ini adalah nilai minimum, nilai maksimum, mean (rata-rata) dan standar deviasi. Uji asumsi klasik pada penelitian ini menggunakan uji multikolinearitas dan uji heteroskedastisitas. Dalam penelitian ini analisis regresi data panel berganda digunakan untuk menguji pengaruh ukuran perusahaan, profitabilitas, dan leverage terhadap manajemen laba dengan rumus:

$$
\text { DA }=\alpha+\beta_{1} \text { LNA }+\beta_{2} \text { ROA }+\beta_{3} \text { DER }+\varepsilon
$$

Dimana:

DA = Manajemen Laba diukur dengan menggunakan Discrenatory Accrual (DA).

LNA = Ukuran Perusahaan diukur dengan menggunakan Log natural Total Aset.

$\mathrm{ROA}=$ Profitabilitas diukur dengan menggunakan Return On Assets (ROA)

DER = Leverage diukur dengan menggunakan Debt to Equity Ratio (DER).

$\alpha \quad=$ Konstanta

$\beta_{1} \quad=$ Koefisien Regresi Ukuran Perusahaan

$\beta_{2} \quad=$ Koefisien Regresi Profitabilitas

$\beta_{3} \quad=$ Koefisien Regresi Leverage

$\varepsilon \quad=$ Error Term 


\section{HASIL DAN PEMBAHASAN}

\section{Analisis Statistik Deskriptif}

Tabel 1. Hasil Analisis Deskriptif

\begin{tabular}{ccccc}
\hline & DA & LNA & ROA & DER \\
\hline Mean & -0.004691 & 28.63321 & 8.391893 & 87.59053 \\
Maximum & 1.190000 & 33.49000 & 92.10000 & 544.2600 \\
Minimum & -0.310000 & 25.80000 & 0.030000 & 9.060000 \\
Std. Dev. & 0.115018 & 1.526461 & 9.551836 & 78.58622 \\
\hline
\end{tabular}

Sumber: Data olahan penulis, 2021

\section{a. Manajemen Laba (Y)}

Berdasarkan hasil pengujian statistik deskriptif diketahui bahwa nilai minimum manajemen laba sebesar -0,31. Sedangkan untuk nilai maksimum manajemen laba sebesar 1,19. Hasil rata-rata dari manajemen laba sebesar -0,004691 dengan nilai standar deviasi sebesar 0,115018 .

b. Ukuran Perusahaan (X1)

Berdasarkan hasil pengujian statistik deskriptif diketahui bahwa nilai minimum ukuran perusahaan sebesar 25,80 . Sedangkan untuk nilai maksimum ukuran perusahaan sebesar 33,49 . Hasil rata-rata dari ukuran perusahaan sebesar 28,63321 dengan nilai standar deviasi sebesar 1,526461 .

c. Profitabilitas (X2)

Berdasarkan hasil pengujian statistik deskriptif diketahui bahwa nilai minimum profitabilitas sebesar 0,03. Sedangkan untuk nilai maksimum profitabilitas sebesar 92,10. Hasil rata-rata dari profitabilitas sebesar 8,391893 dengan nilai standar deviasi sebesar 9,551836

\section{d. Leverage (X3)}

Berdasarkan hasil pengujian statistik deskriptif diketahui bahwa nilai minimum leverage sebesar 9,06. Sedangkan untuk nilai maksimum leverage sebesar 544,26. Hasil rata-rata dari leverage sebesar 87,59053 dengan nilai standar deviasi sebesar 78,58622.

\section{Pemilihan Model Regresi Data Panel}

Regresi data panel dapat dilakukan dengan tiga model yaitu common, fixed dan random effect. Langkah pertama yang harus dilakukan adalah memilih model dari ketiga yang tersedia. Data panel yang telah dikumpulkan, diregresikan dengan menggunakan metode common effect yang hasilnya dapat dilihat pada Tabel 1 sedangkan untuk hasil regresi dengan model fixed effect dapat dilihat pada Tabel 2. 
Tabel 2. Hasil Regresi Data Panel Menggunakan Common Effect

\begin{tabular}{crlll}
\hline \hline Variable & Coefficient & Std. Error & t-Statistic & Prob. \\
\hline \hline LNA? & -0.001279 & 0.000420 & -3.043690 & 0.0026 \\
ROA? & 0.004881 & 0.000713 & 6.844423 & 0.0000 \\
DER? & -0.000109 & $8.62 \mathrm{E}-05$ & -1.259165 & 0.2092 \\
\hline \hline Root MSE & 0.104433 & R-squared & 0.172187 \\
Mean dependent var & -0.004691 & Adjusted R-squared & 0.165288 \\
S.D. dependent var & 0.115018 & S.E. of regression & 0.105083 \\
Akaike info criterion & -1.655857 & Sum squared resid & 2.650204 \\
Schwarz criterion & -1.612732 & Log likelihood & 204.1866 \\
Hannan-Quinn criter. & -1.638486 & Durbin-Watson stat & 1.367375 \\
\hline \hline
\end{tabular}

Tabel 3. Hasil Regresi Data Panel Menggunakan Fixed Effect

\begin{tabular}{ccccc}
\hline \hline Variable & Coefficient & Std. Error & t-Statistic & Prob. \\
\hline \hline C & -0.344813 & 1.137772 & -0.303060 & 0.7622 \\
LNA & 0.009211 & 0.039943 & 0.230604 & 0.8179 \\
ROA & 0.011556 & 0.001079 & 10.70727 & 0.0000 \\
DER & -0.000235 & 0.000232 & -1.012788 & 0.3127 \\
\hline \hline
\end{tabular}

Cross-section fixed (dummy variables)

\begin{tabular}{lrll}
\hline \hline Root MSE & 0.061532 & R-squared & 0.712620 \\
Mean dependent var & -0.004691 & Adjusted R-squared & 0.562603 \\
S.D. dependent var & 0.115018 & S.E. of regression & 0.076068 \\
Akaike info criterion & -2.047171 & Sum squared resid & 0.920034 \\
Schwarz criterion & -0.839693 & Log likelihood & 332.7312 \\
Hannan-Quinn criter. & -1.560810 & F-statistic & 4.750286 \\
Durbin-Watson stat & 2.676260 & Prob(F-statistic) & 0.000000 \\
\hline \hline
\end{tabular}

Setelah hasil dari model common effect dan fixed effect diperoleh maka selanjutnya dilakukan uji chow. Pengujian ini dibutuhkan untuk memilih model yang paling tepat diantara model common effect dan fixed effect. 
Tabel 4. Hasil Uji Chow

\begin{tabular}{crrr}
\hline \hline Effects Test & Statistic & d.f. & Prob. \\
\hline \hline Cross-section F & 3.692959 & $(80,159)$ & 0.0000 \\
Cross-section Chi-square & 255.187541 & 80 & 0.0000 \\
\hline
\end{tabular}

Berdasarkan hasil dari uji chow pada Tabel 3 menunjukkan bahwa nilai probabilitas Cross-section Chi-square adalah 0,0000 atau < 0,05, maka model yang dipilih adalah fixed effect. Selanjutnya dilakukan regresi dengan model random effect untuk menentukan model mana yang tepat. Hasil regresi dengan menggunakan model random effect dapat dilihat pada Tabel 5.

Tabel 5. Hasil Regresi Data Panel Menggunakan Random Effect

\begin{tabular}{|c|c|c|c|c|}
\hline Variable & Coefficient & Std. Error & t-Statistic & Prob. \\
\hline $\mathrm{C}$ & 0.202693 & 0.163569 & 1.239188 & 0.2165 \\
\hline LNA? & -0.009070 & 0.005736 & -1.581119 & 0.1152 \\
\hline ROA? & 0.007201 & 0.000753 & 9.567334 & 0.0000 \\
\hline DER? & $-9.27 \mathrm{E}-05$ & 0.000103 & -0.900849 & 0.3686 \\
\hline \multicolumn{5}{|c|}{ Weighted Statistics } \\
\hline Root MSE & 0.079997 & \multicolumn{2}{|c|}{ R-squared } & 0.257153 \\
\hline Mean dependent var & -0.002625 & \multicolumn{2}{|c|}{ Adjusted R-squared } & 0.247829 \\
\hline S.D. dependent var & 0.093008 & \multicolumn{2}{|c|}{ S.E. of regression } & 0.080664 \\
\hline Sum squared resid & 1.555080 & \multicolumn{2}{|c|}{ F-statistic } & 27.57838 \\
\hline Durbin-Watson stat & 1.940600 & \multicolumn{2}{|c|}{$\operatorname{Prob}($ F-statistic) } & 0.000000 \\
\hline
\end{tabular}

Setelah melakukan uji chow untuk memilih model common effect atau fixed effect, maka selanjutnya dilakukan uji hausman untuk memilih model random effect atau fixed effect. Pada Tabel 5 disajikan hasil uji hausman berikut.

Tabel 6. Hasil Uji Hausman

\begin{tabular}{cccc}
\hline \hline Test Summary & Chi-Sq. Statistic & Chi-Sq. d.f. & Prob. \\
\hline \hline Cross-section random & 32.748298 & 3 & 0.0000 \\
\hline
\end{tabular}


Berdasarkan hasil uji hausman di atas, dapat dilihat dari nilai probabilitas Cross-section random yakni sebesar $0,0000<0,05$, ini berarti model yang terpilih yakni Fixed Effect Model (FEM). Hasil uji chow dan uji hausman menyatakan bahwa model yang terpilih adalah Fixed Effect Model (FEM). Untuk uji lagrange multiplier tidak perlu dilakukan, dikarenakan hasil dari uji chow dan uji hausman telah konsisten, yaitu memilih model Fixed Effect.

\section{Uji Asumsi Klasik}

\section{Uji Multikolinearitas}

Tabel 7. Hasil Uji Multikolinearitas

\begin{tabular}{cccc}
\hline & LNA & ROA & \multicolumn{1}{c}{ DER } \\
\hline \hline LNA & 1.000000 & 0.147507 & 0.040806 \\
ROA & 0.147507 & 1.000000 & -0.061153 \\
DER & 0.040806 & -0.061153 & 1.000000 \\
\hline
\end{tabular}

Berdasarkan pengujian terhadap nilai koefisien korelasi di atas, masing-masing variabel mempunyai nilai koefisien $<0.9$, maka dapat disimpulkan bahwa model tidak mengalami masalah multikolinearitas.

\section{Uji Heteroskedastisitas}

Tabel 8. Uji Heteroskedastisitas

\begin{tabular}{cccc}
\hline \multicolumn{4}{c}{ Heteroskedasticity Test: ARCH } \\
\hline \hline F-statistic & 1.328572 & Prob. F(3,236) & 0.2657 \\
Obs*R-squared & 3.985952 & Prob. Chi-Square(3) & 0.2630 \\
\hline \hline
\end{tabular}

Berdasarkan hasil uji heteroskedastisitas di atas menunjukkan nilai p-value $O b s^{*} R$ square $0,2630>0.05$ sehingga dapat diartikan bahwa dalam penelitian ini tidak ada heteroskedastisitas atau data sudah bersifat homogen.

\section{Analisis Regresi Data Panel Berganda}

Berdasarkan pada Tabel 3 Hasil Regresi Data Panel Menggunakan Fixed Effect (FEM) yang telah terpilih, dapat disusun persamaan regresi data panel berganda sebagai berikut.

$$
\text { DA = -0,344813 + 0,009211 LNA + 0,011556 ROA - 0,000235 DER + } \varepsilon
$$

Berdasarkan koefisien regresi untuk masing-masing variabel independennya dapat diinterpretasikan sebagai berikut.

1. Konstanta (a) $=-0,3448$.

Nilai konstan sebesar -0,3448 menyatakan apabila variabel SIZE, ROA dan DER memiliki nilai sama dengan nol (0), maka variabel dependen DA sebesar -0,3448. 
2. Ukuran Perusahaan $($ LNA $)=0,0092$.

Nilai koefisien regresi variabel ukuran perusahaan (LNA) terhadap variabel manajemen laba (DA) artinya jika ukuran perusahaan mengalami kenaikan satu satuan, maka manajemen laba akan mengalami peningkatan $0,09 \%$, dengan koefisien bernilai positif menunjukkan antara ukuran perusahaan (LNA) dan manajemen laba (DA) mempunyai hubungan positif.

3. Profitabilitas $(\mathrm{ROA})=0,0115$

Nilai koefisien regresi variabel profitabilitas (ROA) terhadap variabel manajemen laba (DA) artinya jika profitabilitas mengalami kenaikan satu satuan, maka manajemen laba akan mengalami peningkatan $0,11 \%$, dengan koefisien bernilai positif menunjukkan antara profitabilitas (ROA) dan manajemen laba (DA) mempunyai hubungan positif.

4. Leverage $(\mathrm{DER})=-0,0002$

Nilai koefisien regresi variabel leverage (DER) terhadap variabel manajemen laba (DA) artinya jika leverage mengalami kenaikan satu satuan, maka manajemen laba akan mengalami penurunan $0,02 \%$, dengan koefisien bernilai negatif menunjukkan antara leverage (DER) dan manajemen laba (DA) mempunyai hubungan negatif.

\section{Uji Hipotesis}

\section{Uji t Statistik}

Hasil uji t Statistik dapat dilihat pada Fixed Effect Model (FEM) di Tabel 3 sebelumnya. Jika nilai probability $\mathrm{t}<0,05$ maka Ha diterima, sedangkan jika nilai probability $\mathrm{t}>0,05$ maka Ha ditolak.

\section{Pengujian Hipotesis Pertama}

Hasil uji regresi data panel berganda diperoleh nilai koefisien regresi sebesar 0,009211. Hal ini menunjukkan bahwa hubungan antara ukuran perusahaan terhadap manajemen laba adalah searah. Variabel ukuran perusahaan mempunyai t hitung sebesar 0,23 dengan signifikansi sebesar 0,8179. Nilai signifikansi t ukuran perusahaan > 0,05 maka dapat disimpulkan bahwa ukuran perusahaan tidak memiliki pengaruh terhadap manajemen laba sehingga hipotesis pertama ditolak.

2. Pengujian Hipotesis Kedua

Hasil uji regresi data panel berganda diperoleh nilai koefisien regresi sebesar 0,011556. Hal ini menunjukkan bahwa hubungan antara profitabilitas terhadap manajemen laba adalah searah. Variabel profitabilitas mempunyai t hitung sebesar 10,70 dengan signifikansi sebesar 0,0000. Nilai signifikansi t profitabilitas < 0,05 maka dapat disimpulkan bahwa profitabilitas memiliki pengaruh terhadap manajemen laba sehingga hipotesis kedua diterima.

\section{Pengujian Hipotesis Ketiga}

Hasil uji regresi data panel berganda diperoleh nilai koefisien regresi sebesar -0,000235. Hal ini menunjukkan bahwa hubungan antara leverage terhadap manajemen laba adalah tidak searah. Variabel leverage mempunyai t hitung sebesar -1,01 dengan signifikansi sebesar 0,3127. Nilai signifikansi t leverage > 0,05 maka dapat disimpulkan bahwa leverage tidak memiliki pengaruh terhadap manajemen laba sehingga hipotesis ketiga ditolak. 


\section{Uji F Statistik}

Berdasarkan hasil pada Fixed Effect Model (FEM) pada Tabel 2, terlihat dari nilai probabilitas yaitu sebesar $0,00000<0,05$ dan Fhitung > Ftabel yaitu 4,839532 > 4,7502 sehingga Ha diterima. Hal ini menunjukkan bahwa variabel ukuran perusahaan, profitabilitas dan leverage secara bersama-sama (simultan) mempunyai pengaruh yang signifikan terhadap manajemen laba, sehingga model regresi dapat digunakan untuk memprediksi variabel dependen.

\section{Uji Determinasi (Adjusted R-square)}

Berdasarkan hasil pada Fixed Effect Model (FEM) pada Tabel 2, diperoleh besar angka Adjusted $R$-Square (R) adalah 0,562603. Hal ini menunjukkan bahwa persentase sumbangan pengaruh variabel independen terhadap variabel dependen adalah sebesar 56\%. Atau dapat diartikan bahwa variabel independen yang digunakan dalam model mampu menjelaskan sebesar $56 \%$ terhadap variabel dependennya. Dan $44 \%$ lainnya dipengaruhi faktor lain di luar model regresi tersebut.

\section{PEMBAHASAN}

\section{Pengaruh Ukuran Perusahaan terhadap Manajemen Laba}

Variabel ukuran perusahaan tidak berpengaruh secara signifikan terhadap manajemen laba. Hasil ini konsisten dengan penelitian sebelumnya oleh Sari (2015) dan Agustia \& Suryani (2018) dan tidak konsisten dengan hasil penelitian Lubis \& Suryani (2018). Hasil Penelitian ini yang berarti bahwa ukuran perusahaan yang besar belum tentu melakukan praktik manajemen laba.

\section{Pengaruh Profitabilitas terhadap Manajemen Laba}

Variabel profitabilitas pada penelitian ini berpengaruh secara positif dan signifikan terhadap manajemen laba. Hasil ini konsisten dengan penelitian sebelumnya oleh Puspitosari (2015) dan Purnama (2017) dan tidak konsisten dengan hasil penelitian Agustia \& Suryani (2018). Hasil penelitian ini menyatakan bahwa profitabilitas berpengaruh positif yang artinya bahwa apabila profitabilitas naik maka perusahaan akan cenderung melakukan praktik manajemen laba.

\section{Pengaruh Leverage terhadap Manajemen Laba}

Variabel leverage pada penelitian ini tidak berpengaruh secara signifikan terhadap manajemen laba. Hasil ini konsisten dengan penelitian sebelumnya oleh Purnama (2017) dan Puspitosari (2015) dan tidak konsisten dengan hasil penelitian Sosiawan (2012). Berdasarkan dari definisi tersebut maka leverage dinilai dapat berpengaruh positif terhadap manajemen laba. Perusahaan yang memiliki rasio leverage yang tinggi belum tentu melakukan praktik manajemen laba. 


\section{PENUTUP}

\section{Simpulan}

Secara Parsial dapat disimpulkan bahwa ukuran perusahaan tidak berpengaruh terhadap manajemen laba pada perusahaan, profitabilitas berpengaruh positif terhadap manajemen laba dan leverage tidak berpengaruh terhadap manajemen laba pada perusahaan manufaktur yang terdaftar di Bursa Efek Indonesia tahun 2017-2019. Sedangkan secara simultan variabel ukuran perusahaan, profitabilitas dan leverage berpengaruh terhadap manajemen laba pada perusahaan manufaktur yang terdaftar di Bursa Efek Indonesia tahun 2017-2019. Koefisien determinasi dapat disimpulkan bahwa variabel independen yang digunakan dalam model mampu menjelaskan sebesar 56\% terhadap variabel dependennya dan sebesar $44 \%$ dipengaruhi faktor lain di luar model regresi tersebut.

\section{Saran}

Adapun saran yang dapat diberikan berdasarkan kesimpulan ini, maka saran dari penelitian ini sebagai berikut.1)Penelitian ini hanya menggunakan variabel ukuran perusahaan, profitabilitas dan leverage sebagai dasar untuk mengukur manajemen laba. Bagi peneliti selanjutnya, hendaknya menambah variabel lain atau memasukkan variabel di luar penelitian ini seperti komite audit, kepemilikan manajerial, kepemilikan institusional, dan pertumbuhan penjualan. 2) Penelitian ini menggunakan periode waktu tiga tahun yaitu 2017-2019, peneliti selanjutnya dapat melakukan pengujian kembali dengan periode waktu dan tahun yang berbeda. 3) Berdasarkan hasil penelitian, para investor dan kreditor sebaiknya lebih berhati-hati dalam menginvestasikan dan meminjamkan dana yang dimilikinya, karena perusahaan dengan profitabilitas yang tinggi terbukti melakukan manajemen laba yang tinggi.

\section{REFERENSI}

Aditama, F., dan Purwaningsih, A. 2014. "The Effect of Tax Planning on Earnings Management in Non-Manufacturing Companies Listed in Indonesia Stock". MODE-Journal of Economics and Business. Hal 33-50. https://doi.org/10.24002/modus.v26i1.576

Agustia, Y. P., dan Suryani, E. 2018. "Pengaruh Ukuran Perusahaan, Umur Perusahaan, Leverage, Dan Profitabilitas Terhadap Manajemen Laba (Studi Pada Perusahaan Pertambangan yang Terdaftar di Bursa Efek Indonesia Periode 2014-2016)". Jurnal ASET (Akuntansi Riset). Hal 71-82. https://doi.org/10.17509/jaset.v10i1.12571

Azlina. 2010. "Analisis Faktor Yang Mempengaruhi Praktik Manajemen Laba". Pekbis Jurnal. Hal 355-363. https://media.neliti.com/media/publications/8960-ID-analisis-faktor-yangmempengaruhi-manajamen-laba-studi-pada-perusahaan-yang-terd.pdf

Bawono, A., dan Shina, I. A. F. 2018. Ekonometrika Terapan untuk Ekonomi dan Bisnis Islam Aplikasi dengan Eviews. Salatiga: LP2M IAIN Salatiga. http://erepository.perpus.iainsalatiga.ac.id

Dechow, et all. 1995. "Detecting Earnings Management". Asian Financial Statement Analysis. Hal 73-105. https://doi.org/10.1002/9781119204763.ch4

DetikFinance. 2004. Kasus Manajemen Laba PT Ades. htpps://finance.detik.com/bursa-danvalas/d-229893/manajemen-baru-ades-berikan-informasi-salah

DetikFinance. 2015. Kasus Manajemen Laba PT Inovisi Infracom Tbk. https://finance.detik.com/bursa-dan-valas/d-2917159/saham-inovisi-dibekukan-4-bulankarena-laporan-keuangan-banyak-salah? 
DetikFinance. 2019. Kasus Manajemen Laba PT Garuda. https://finance.detik.com/bursa-danvalas/d-4640204/kronologi-laporan-keuangan-garuda-dari-untung-jadi-buntung.

Dewi, L. S., dan Ulupui, I. G. K. A. 2014. "Pengaruh Pajak Penghasilan Dan Asset Perusahaan Pada Earnings Management". E-Jurnal Akuntansi Universitas Udayana. Hal 250-259. https://doi.org/10.24843/EJA.2021.v31.i08

Gunawan, I. K., Darmawan, N. A. S., dan Purnamawati, I. G. A. 2015. "Pengaruh Ukuran Perusahaan, Profitabilitas, dan Leverage Terhadap Manajemen Laba". Jurnal Akuntansi Program S1 Universitas Pendidikan Ganesha. https://doi.org/10.23887/jimat.v3i1.5272

Harahap, Sofyan Safri. 2013. Analisa Kritis atas Laporan Keuangan. Jakarta: PT Grafindo Persada

Herispon. 2016. Financial Statement Analysis. Pekanbaru: Akademi Keuangan \& Perbankan Riau. https://books.google.co.id/

Ikatan Akuntan Indonesia. 2009. Standar Akuntansi Entitas Tanpa Akuntabilitas Publik. Jakarta: Ikatan Akuntan Indonesia. http://ww.iaiglobal.or.id

Ismayani. 2020. Metodologi Penelitian. Aceh: Syiah Kuala University Press. https://books.google.co.id/

Kasmir. 2016. Pengantar Manajemen Keuangan. Jakarta: Prenada Media. https://books.google.co.id/

Kasmir, S. E., dan Jakfar, S. 2013. Studi Kelayakan Bisnis. Jakarta: Prenada Media. https://books.google.co.id/

Lubis, I., dan Suryani. 2018. "Pengaruh Tax Planning, Beban Pajak Tangguhan dan Ukuran Perusahaan Terhadap Manajemen Laba (Studi Empiris pada Perusahaan Industri Barang Konsumsi di Bursa Efek Indonesia Tahun 2012 - 2016)". Jurnal Akuntansi Dan Keuangan, 7(22527141). Hal 41-58. https://journal.budiluhur.ac.id/index.php/akeu/article/view/584

Nurdin, I., dan Hartati, S. 2019. Metodologi Penelitian Sosial. Surabaya: Media Sahabat Cendekia. https://books.google.co.id/

Nuryanto, dan Pambuko, Z. B. 2018. Eviews Untuk Analisis Ekonometrika Dasar Aplikasi dan Interpretasi. Magelang: UNIMMA PRESS. https://books.google.co.id/

Purnama. 2017. "Pengaruh Profitabilitas, Leverage, Ukuran Perusahaan, Kepemilikan Institusional Dan Kepemilikan Manajerial Terhadap Manajemen Laba". Jurnal Riset Keuangan Dan Akuntansi. Hal 1-14. https://doi.org/10.25134/jrka.v3i1.676

Puspitosari. 2015. "Analisis Faktor-Faktor yang Berpengaruh terhadap Manajemen Laba pada Perbankan Syariah Periode 2010-2013". MIX: Jurnal Ilmiah Manajemen. htpps://mix.mercubuana.ac.id/

Santoso. 2016. Panduan Lengkap SPSS Versi 23. Jakarta: Elex Media Komputindo. https://books.google.co.id/

Sari. 2015. "Analisis Faktor-Faktor Yang Mempengaruhi Manajemen Laba Pada Perusahaan Manufaktur Yang Terdaftar Di Bursa Efek Indonesia". JOMFekon. Hal 1-15. https://media.neliti.com/media/publications/125589-ID-analisis-dampak-pemekarandaerah-ditinja.pdf

Setiawati, L., dan Na'im, A. 2000. "Manajemen laba". Jurnal Ekonomi Dan Bisnis Indonesia. Hal 424-441. https://journal.ugm.ac.id/jieb/article/view/39145

Siyoto, S., dan Sodik, A. 2015. Dasar Metodologi Penelitian. Yogyakarta: Literasi Media Publishing. https://books.google.co.id/ 
Sosiawan. 2012. "Pengaruh Leverage, Ukuran Perusahaan dan Earning Power Terhadap Manajemen Laba". Akuntansi \& Bisnis. Hal 79-89. https://doi.org/10.21460/jrak.2012.81.173

Sudana. 2011. Manajemen Keuangan Teori dan Praktik. Surabaya: Airlangga University Press. https://books.google.co.id/

Sudana. 2019. Manajemen Keuangan Teori dan Praktik. Surabaya: Airlangga University Press. https://books.google.co.id/

Sulistyanto. 2008. Manajemen Laba Teori dan Model Empiris. Jakarta: Grasindo. https://books.google.co.id/

Sumiati, dan Indrawati, N. K. 2019. Manajemen Keuangan Perusahaan. Malang: Universitas Brawijaya Press. https://books.google.co.id/

Tempo.co. 2003. Kasus Manajemen Laba PT Kimia Farma. https://bisnis.tempo.co/read/33339/bapepam-kasus-kimia-farma-merupakan-tindak-pidana.

Wibisana, I. D., dan Ratnaningsih, D. 2014. "Analisis Faktor - Faktor Yang Mempengaruhi Arah Manajemen Laba (Studi Pada Perusahaan Manufaktur Yang Terdaftar di BEI 20092013)". E-Jurnal Universitas Atma Jaya. Hal 1-13. http://e-journal.uajy.ac.id

Widodo, A., dan Andawaningtyas, K. 2017. Pengantar Statistika. Malang: Universitas Brawijaya Press. htpps://books.google.co.id/

Wijaya. 2017. Manajemen Keuangan Konsep dan Penerapannya. Jakarta: Gramedia. https://books.google.co.id/ 